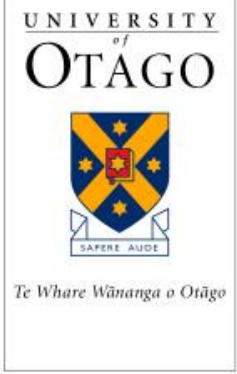

ISSN 0111-1760 (Print)

ISSN 1178-2293 (Online)

University of Otago

Economics Discussion Papers

No. 0801

School of Business

Unlimited Future, Unlimited Possibilities

Te Kura Pakihi

January 2008

\title{
Is there a dirty little secret? Non-tariff barriers and the gains from trade
}

\author{
Niven Winchester ${ }^{*}$
}

Correspondence to:

Niven Winchester

Department of Economics

University of Otago

P.O. Box 56

Dunedin 9054

New Zealand

Email: nwinchester@business.otago.ac.nz

Tel: + 6434798648

Fax: + 6434798174

\footnotetext{
${ }^{*}$ I would like to thank Russel Hillberry, John Ballingall, Gus Charteris and seminar participants at the University of Nottingham, OECD and the Tenth Annual Conference on Global Economic Analysis for helpful comments and suggestions. Remaining errors are my responsibility.
} 


\begin{abstract}
We estimate tariff equivalents (TEs) of non-tariff barriers (NTBs) using a series of gravity equations. Our analysis focuses on New Zealand, a nation that has a comprehensive free trade agreement (with Australia) that can be used to benchmark other trade negotiations. We estimate reductions in TEs following trade negotiations as differences between New Zealand-Australia TEs and those applying to trade between New Zealand and other nations. Simulating reductions in tariffs and NTBs in a computable general equilibrium (CGE) model indicates that gains from trade liberalisation are much larger when tariffs and NTBs are consider than when only tariffs are reduced.
\end{abstract}

Key words: trade liberalisation, non-tariff barriers, computable general equilibrium modelling

JEL codes: F15, D58 


\section{Introduction}

Krugman (1995, p. 31) notes, "there is a dirty little secret in international trade analysis. The measurable costs of protectionist policies... are not all that large." Conventional trade liberalisation examinations, however, typically only consider trade distortions that result in rents flowing to domestic agents, such as tariffs and quotas. That is, most analyses ignore more subtle (and sometimes unintended) trade barriers that involve real resource costs and are therefore likely to result in greater welfare losses than tariffs and quotas. ${ }^{1}$ Such barriers are commonly referred to as non-tariff barriers (NTBs) and include health and safety regulations, competition laws, technical standards (e.g., licensing and certification regimes) and customs clearance procedures (Philippidis and Sanjuán, 2007a). Anderson and van Wincoop (2001, p. 209) highlight the real resource cost of such barriers by noting that NTBs may necessitate "gathering information about foreign regulations, hiring lawyers, and adjusting product designs to make them consistent with foreign customs regulations."

Trade negotiations typically cover issues broader than tariff reductions. We estimate ad valorem tariff equivalents (TEs) of NTBs and simulate reductions in tariffs and NTBs in a computable general equilibrium (CGE) model. Building on studies by Park (2002), Lejour et al. (2004), Philippidis and Carrington (2005) and Philippidis and Sanjuán (2007a, 2007b) we estimate TEs using a series of gravity equations. This approach allows NTBs applying to a particular bilateral route to be compared to those that would exist in a free trade scenario. Our analysis singles out TEs faced by New Zealand exports to Australia and four possible Free Trade Area (FTA) partners, and

\footnotetext{
${ }^{1}$ As is well known, quotas can also result in real resource costs if there is rent seeking behaviour.
} 
TEs levied on New Zealand imports from Australia and other regions. To reflect the resource cost of NTBs, we represent these barriers as iceberg transport costs.

We focus on New Zealand as examining trade for this nation allows us to benchmark NTBs applying to trade between New Zealand and potential FTA partners against NTBs that would exist following several rounds of far-reaching negotiations. ${ }^{2}$ This is because, as a member of the Australia and New Zealand Closer Economic Relations (CER) Trade Agreement, New Zealand is privy to one of the most comprehensive FTAs in the world. The two Australasian nations signed the New Zealand-Australia Free Trade Agreement in 1965 (a limited preferential trade agreement), which was superseded by the CER Agreement in 1983. Free trade in goods and services was achieved in 1990 and subsequent negotiations have focused on other aspects of economic integration. For example, the Trans-Tasman Mutual Recognition Agreement, launched in 1998, allows most goods legally able to be sold in one CER nation to be sold in the other CER nation without undergoing further testing. We estimate potential gains from trade liberalisation by assuming that negotiations can reduce NTBs between New Zealand and possible FTA partners to NTBs applying to trade within the CER .

Similar to other authors (e.g., Lejour et al., 2004; Philippidis and Sanjuán, 2007a, 2007b) we find that TEs in agro-food sectors are larger than TEs in other sectors. Our simulations reveal that bilateral negotiations between New Zealand and four possible

\footnotetext{
${ }^{2}$ New Zealand has also energetically pursued FTA partners in recent years. Specifically, New Zealand signed the New Zealand and Singapore Closer Economic Partnership in 2001 (which was subsumed by the Trans-Pacific Strategic Economic Partnership between New Zealand, Singapore, Chile and Brunei Darussalam in 2005), the New Zealand-Thailand Closer Economic Partnership Agreement in 2005, and is currently negotiating FTAs with the Association of South East Asian Nations (ASEAN), China, the Gulf Cooperation Council, Hong Kong, and Malaysia.
} 
FTA partners (China, Japan, Korea, and the ASEAN block) will increase New Zealand welfare by $1.5 \%$ when tariffs are eliminated and $16.3 \%$ when tariffs and NTBs are abolished. In other words, we show that although a conventional approach produces a small welfare increase, a broader analysis produces a substantial welfare improvement. We also find that, contrary to other studies, nearly half of New Zealand's gains from trade originate from the liberalisation of manufacturing trade.

This paper has three further sections. Section 2 details our estimates of TEs of NTBs. Section 3 outlines our CGE model and details results from our simulation exercises. The final section concludes.

\section{Tariff equivalents of non-tariff barriers}

Ferrantino (2006) identifies three approaches used to quantify TEs of NTMs: "handicraft" price gap methods, price-based econometric approaches, and quantitybased econometric methods. Handicraft methods estimate the price gap between domestic prices and international prices. Price-based econometric methods take advantage of systematic reasons why prices in some countries are higher than prices in other countries. Quantity-based econometric methods infer the impact of NTMs by comparing actual trade flows with a "free trade" benchmark.

Handicraft approaches are generally considered to be more accurate than "mass produced" econometric methods but the data and time required to implement a handicraft study across many products and countries can be unreasonable. We estimate TEs of NTBs using a series of gravity equations as this approach uses easily accessible trade data. In its simplest form, the gravity model predicts that bilateral 
trade flows are increasing in the exporter's production and the importer's consumption and decreasing in distance between two nations. More sophisticated models add other variables to proxy for trade costs, such as whether or not two nations share a common border. We estimate the following gravity equation.

$$
x_{i j}=\beta_{0}+\beta_{1} \operatorname{prod}_{i}+\beta_{2} \text { cons }_{j}+\sum_{m=1}^{M} \beta_{\mathrm{m}} \ln \left(Z_{i j}^{m}\right)+\varepsilon_{i j}
$$

where logged variables are in lower case; $x_{i j}$ denotes exports from region $i$ to $j$; $\operatorname{prod}_{i}$ is production in country $i$, cons $_{j}$ is consumption in country $j, \mathrm{z}^{\mathrm{m}}$ is a set of observables to which bilateral trade barriers are related, and $\varepsilon_{i j}$ is an error term.

Observable bilateral trade barriers we control for include the log of distance between regions $i$ and $j$ (distance); dummy variables equal to one if regions $i$ and $j$, respectively, share a common border (contiguous), a colonial relationship (colonial) or a common language (language); the log of one plus the ad valorem tariff imposed by region $j$ on imports from $i$ (tariff); the $\log$ of one plus the ad valorem export subsidy paid to exporters in region $i$ for goods shipped to country $j$ (esub); and dummy variables equal to one if $i$ and $j$ are, respectively, members of NAFTA, the EU15 or MERCOSUR. ${ }^{3}$

Gravity equations can be used to determine the influence of international borders on trade by comparing international trade flows with domestic trade flows (see, for example, McCallum, 1995 and Anderson and van Wincoop, 2003). Accordingly, we

\footnotetext{
${ }^{3}$ We do not include the 10 nations granted EU membership in 2004 in the EU as our analysis uses 2001 data.
} 
also include several dummy variables to capture impediments caused by international borders. Specifically, $b_{N Z L, A U S}, b_{N Z L, C H N}, b_{N Z L, J P N}, b_{N Z L, K O R}$ and $b_{N Z L, A S N}$ equal one if the dependent variable measures New Zealand's exports to, respectively, Australia, China, Japan, Korea or ASEAN; $b_{A U S, N Z L}$ and $b_{O T H, N Z L}$ equal one if $x_{i j}$ relates to New Zealand imports from, respectively, Australia or any region except Australia; and $b_{O T H E R}$ is equal to one if exports cross any international border not previously identified. We also include separate dummies for each exporter and importer to account for multilateral resistance (Anderson and van Wincoop, 2003).

We source data on bilateral international trade flows, bilateral tariffs, bilateral export subsidies, production and consumption from version 6 of the Global Trade Analysis Project (GTAP) database (Dimaranan, 2006). Following Wei (1996), we estimate a nation's exports to itself by subtracting each nation's aggregate exports (to all international destinations) from its domestic production. The GTAP database identifies 87 regions and 57 sectors. We filter GTAP's regional data by omitting composite regions identified in the GTAP database (Rest of Oceania, Rest of East Asia etc) and nations with GDP less than US\$30 billion. Forty-seven countries, which are listed in Table A.1, are included in our regression analysis. We organise the sectoral data by forming 23 aggregated sectors, which are listed in Table 4. Our sectoral aggregation includes New Zealand's important export commodities (e.g., meat and dairy products), commodities used intensively as intermediate inputs by New Zealand's key export industries (e.g., animal products and raw milk) and New 
Zealand's sensitive import-competing industries (e.g., textiles clothing and footwear $(\mathrm{TCF}))^{4}$

For distance, we employ harmonic-mean weighted distance measures available from the Centre D'Etudes Prospectives et D'Informations Internationales (CEPII). ${ }^{5}$ Guided by Head and Mayer (2002), CEPII calculate bilateral distance between two countries as population-weighted average distances between the major cities belonging to those two countries. One advantage of this measure it that it provides a consistent procedure for calculating both internal distance, which is calculated using an approximation based on a each region's land area, and international distances. Data for our dummy variables capturing the effects of contiguity, sharing a colonial relationship (equal to one if two nations have had a colonial relationship after 1945) and speaking a common language (equal to one if a language is spoken by at least $9 \%$ of the population in both nations) are also sourced from CEPII.

Guided by Silva and Tenreyro (2006), we estimate equation (1) using the Poisson pseudo-maximum likelihood (PPML) estimator. That is, we implement a Poisson regression of exports on the logarithm of distance, contiguous, common language and colonial heritage dummy variables, the logarithm of one plus the relevant import tariff, the logarithm of one plus the relevant export subsidy, border dummy variables, and importer and exporter fixed effect dummy variables. ${ }^{6}$ As the PPML estimator is

\footnotetext{
${ }^{4}$ We do not include "raw milk" and "other services" in our gravity regression as these sectors are largely non-traded.

${ }^{5}$ See http://www.cepii.fr/anglaisgraph/bdd/distances.htm.

${ }^{6}$ Silva and Tenreyro (2006) show that estimating the gravity equation in multiplicative form using the (PPML) estimator has several advantages over applying OLS to the log-linear model. First, using Jensen's inequality the authors show that estimating a gravity equation in logarithms using OLS can lead to severely biased and inconsistent estimates when heteroskedastcity is present. Second, as the logarithm of zero is undefined, the sample must be truncated or the dependent variable rescaled when exports between a particular pair of countries are zero.
} 
unlikely to fully account for heteroskedastcity we base inference on robust standard errors.

Results from estimating equation (1) after pooling observations across agro-food sectors (vegetables and fruit - other food), manufacturing sectors (textiles, clothing and footwear - other manufacturing), service sectors (trade and transport - public services) and all sectors are displayed in Table 1. Most coefficients have the expected signs and are statistically significant. The distance coefficients imply that the impact of geography on trade is greatest for agro-food sectors and smallest for service sectors. Like Silva and Tenreyro (2006), we find that the elasticity of trade flows with respect to distance is much less than one. Production and consumption have a positive effect on trade flows, except in the manufacturing equation, where only production influences exports.

Nations that share a common border are expected to trade $47.4 \%(=\exp (0.388)-1)$ more than nations that are disjoined in the all-sectors regression, but contiguity does not influence trade in services. Similarly, having a colonial relationship after 1945 has a positive effect on trade in the agro-food, manufacturing and all-sectors regressions but not in the services equation. Sharing a common language increases trade in all sectors and has the largest influence on agro-food trade. With the exception of manufacturing tariffs, tariffs and export subsidies either do not have a statistically significant effect on trade or influence trade in a counterintuitive way. This is not uncommon in gravity equations (see, for example, Philippidis and Sanjuán, 2007a, 
2007b). ${ }^{7}$ NAFTA and EU membership have a positive effect on trade in all regression but MERCOSUR allegiance only increases exports in the agro-food regression. Estimates for the NAFTA and EU dummy variables are in broad agreement with those produced by other authors (See, for example, Anderson and van Wincoop, 2003 and Silva and Tenreyro, 2006).

The most important estimates from our point of view are those relating to the influence of international borders. As highlighted by Anderson and van Wincoop (2003), after controlling for distance and other factors, the ratio of $i$ 's exports to $j$ to $i$ 's exports to itself is given by the exponential of the coefficient on the $i-j$ border dummy, $b_{i j}$. So, in the all-sectors regression, New Zealand's (conditional) exports to Australia are $30.0 \%(=\exp (-1.348))$ of New Zealand's self exports. Corresponding figures for New Zealand's exports to China, Japan, Korea, ASEAN and other regions are $14.3 \%, 24.1 \%, 17.4 \%$, and $20.7 \%$. These figures indicate that New Zealand goods shipped to Australia face lower NTBs than goods transported to other nations. Additionally, comparing the coefficients on $b_{A U S, N Z L}$ and $b_{O T H, N Z L}$ suggests that NTBs applying to New Zealand imports from Australia are lower than NTBs pertaining to New Zealand imports from elsewhere.

Turning to estimates of border effects for different divisions, the first column of results reveals that impediments to agro-food trade between New Zealand and Australia are lower than those applying to New Zealand agro-food trade with other nations (in both directions). Moreover, the estimates indicate that the CER agreement

\footnotetext{
${ }^{7}$ Philippidis and Sanjuán (2007b) note that the unexpected results for tariffs could be because tariffs are commonly used to protected sensitive sectors for which nations have a comparative disadvantage. The authors also note that export subsidies are negatively correlated with comparative advantage as most observations for this variable relate to agricultural exports from the EU.
} 
has reduced the influence of international borders on agro-food trade to a larger extent than it has reduced border effects for trade in other commodities. The manufacturing regression results suggest that there is a inverted New Zealand-Australia border effect (i.e., the New Zealand-Australia border results in greater New Zealand exports than would be expected given distance and other characteristics of the bilateral relationship) and that Chinese, Japanese, Korean and ASEAN borders do not impede New Zealand exports. These results are unexpected but may reflect the small size of the New Zealand economy. That is, New Zealand manufacturers may be forced to gear production towards overseas markets in order to take advantage of economies of scale.

Despite these unexpected observations, relative border effects indicate that it is easier for New Zealand goods to enter Australia than other overseas markets. Likewise, the data suggest that hurdles facing New Zealand imports of manufacturing from its CER partner are lower than those opposing New Zealand imports from other nations. Border effects in the services regression are strikingly large. For example, New Zealand's services exports to Australia are only $0.15 \%$ of New Zealand's (conditional) domestic exports, which may reflect the non-tradable nature of this sector. The results also indicate that New Zealand service providers have greater access to markets in China, Japan, Korea and ASEAN than in Australia (i.e., the CRE agreement appears to have had little impact on trade in services). Overall, with the exception of services, the estimated border coefficients in Table 1 give a strong indication that NTBs applying to New Zealand-Australia trade are less than those applying to New Zealand's trade with other nations. This finding validates our use of 
Australia-New Zealand NTBs to benchmark NTBs applying to trade between New Zealand and other nations.

We calculate sectoral border effects by estimating equation (1) for each sector. ${ }^{8}$ Regression results are reported in Tables A.2 and A.3 and we indicate the frequency for which each variable is (a) significant and has a correct sign, (b) significant and has an incorrect sign, and (c) insignificant, where statistical significance is inferred using a five percent critical value. Like in our previous analyses, distance, which is significant and has a correct sign in all regression, is an important determinant of trade flows. The explanatory power of our contiguous and colonial variables is mixed. Coefficients on these variables are only significant and of the correct sign in around one-third of equations. Surprisingly, neither variable is significant and of the correct sign in our service regressions, although this result is consistent with the findings of Lejour et al. (2004) and Philippidis and Sanjuán (2007b). Sharing a common language is a significant determinant of trade flows in all service sectors and just over $80 \%$ of all regressions. Three of the four insignificant language coefficients are in agro-food sectors. Tariffs have a mixed effect on agricultural trade but a negative effect on trade in five of the six manufacturing equations. Export subsidies also have greater explanatory power in manufacturing sectors (positive and significant in four of six equations) than agro-food sectors (positive and significant in one out of seven equations).

Turning to the FTA coefficients, like in our aggregated regressions, EU and NAFTA membership have a greater positive influence on trade flows than MERCOSUR

\footnotetext{
${ }^{8}$ We do no include production and consumption in our sectoral regressions due to colinearity between, respectively, production and exporter fixed-effects, and consumption and importer fixed effects.
} 
association. Sectoral comparisons of the FTA variables reveal that FTA membership enhances trade in agro-food sectors (significant in $73.3 \%$ of occasions) more than manufacturing (55.5\%) and services (20.0\%). Regarding border effects, four of the five positive border coefficients (which represent inverted border effects) are in manufacturing and an equal proportion is associated with the New Zealand-Australia border. All positive border effects (New Zealand-Australia border dummies in fishing, TCF, chemicals and other equipment, and the New Zealand-Japan border dummy for chemicals) are associated with large export-to-output ratios. For example, 14.6\% of New Zealand's TCF output is exported to Australia whereas the corresponding figure for manufacturing as a group is $8.8 \%$. The large proportion of positive or insignificant border coefficients $(70 \%)$ lends support to our hypothesis that most New Zealand manufacturers produce for foreign rather than domestic markets. Like in our aggregated regressions, the results indicate that, in general, trans-Tasman trade in agro-food and manufacturing faces fewer impediments than trade elsewhere but this is not the case for services.

Anderson and van Wincoop (2003), show that the ad valorem tariff equivalent of border barriers facing exports from country $i$ to country $j, t_{i j}^{*}$, is given by. ${ }^{9}$

$$
t_{i j}^{*}=\exp \left[\beta_{i j} /\left(1-\sigma_{i j}\right)\right]-1
$$

\footnotetext{
9 An alternative method for determining TEs of NTBs is the residual approach. This technique computes the ratio of actual to predicted trade flows normalised to a free trade benchmark, commonly defined as the country with the largest positive difference between actual and predicted trade flows. This ratio can be combined with an estimate of the elasticity of substitution to estimate TEs (Park, 2002; Philippidis and Carrington, 2005; and Philippidis and Sanjuán, 2007a, 2007b). We favour the dummy variable approach described above as this method allows our estimating equation to recognise border barriers and may result in improved econometric estimates.
} 
where $\beta_{i j}$ is the coefficient applying to the border dummy $b_{i j}$, and $\sigma$ is the elasticity of substitution between goods, which we calculate as a weighted average of elasticities of substitution between domestic and imported varieties, $\sigma^{D M}$, and between imports by country of origin, $\sigma^{M M}$ sourced from the GTAP database. ${ }^{10}$ Specifically,

$$
\sigma_{i j}=\alpha_{i j} \sigma^{D M}+\left(1-\alpha_{i j}\right) \sigma^{M M}
$$

where $\alpha_{i j}$ is the proportion of $j$ 's imports sourced from $i$.

As we control for transport costs, tariffs and exports subsidies, we assume that border costs reflect NTBs. We also presuppose that trade negotiations can reduce NTBs facing New Zealand exports to non-Australian markets to those applying to New Zealand exports to Australia. Specifically, we calculate CER-normalised TEs of NTBs facing New Zealand exports to country $j$ by subtracting $t_{n z l, a u s}^{*}$ from $t_{n z l, i}^{*}$ if $t_{n z l, i}^{*}>t_{n z l, a u s}^{*}$. In cases where $t_{n z l, a u s}^{*}>t_{n z l, i}^{*}$, we assume that trade negotiations will not change NTBs as an increase in impediments to trade following trade discussions seems unlikely. Similarly, we estimate trade negotiation-induced reductions in NTBs applying to New Zealand imports by calculating CER-normalised TEs as $t_{i, n z l}^{*}$ $t_{\text {aus }, n z l}^{*}$ if $t_{i, n z l}^{*}>t_{\text {aus }, n z l}^{*}$, zero otherwise.

CER-normalised tariffs are reported in Table 3. TEs of $300 \%$ or more are not uncommon in agro-food sectors, which is consistent with other estimates of TEs (see, for example, Philippidis and Sanjuán, 2007a, 2007b). The ad valorem tariff equivalent

${ }^{10} \sigma^{D M}$ and $\sigma^{M M}$ are not indexed by $i$ and $j$ as elasticities do not differ across countries in the GTAP database. 
on New Zealand's fish exports to China, however, seems implausible. Consequently, we replace this number with the next highest tariff equivalent applying to New Zealand's fish exports, 579\%. There are also significant TEs on New Zealand meat and dairy products shipped abroad. In other sectors, all New Zealand manufacturing imports face relatively high TEs and TEs applying to New Zealand's imports and exports of services are zero in most cases. In general, the numbers suggest the removal of NTBs on New Zealand's agro-food exports and manufacturing imports will generate larger benefits than the removal of tariffs elsewhere.

\section{Modelling framework and results}

Our modelling exercises utilise Rutherford's (2005) GTAP6inGAMS model and Version 6 of the GTAP database. GTAP6inGAMS is a static, perfectly competitive, global CGE model that captures both bilateral trade flows and inter-sectoral linkages within regions. Intra-industry trade flows are facilitated by the Armington assumption (Armington 1969). That is, composite imports are differentiated from domestic products and imports are differentiated by country of origin using a multi-level constant elasticity of substitution nest. There is a representative firm in each sector that gathers intermediate inputs, which are composites of domestically produced and imported varieties, and a primary factor composite, which is a Cobb-Douglas aggregation of primary factors. Factor prices are endogenous so there is full employment, and factors are perfectly mobile across sectors (but immobile internationally). Consumption is governed by a representative consumer in each region, which allocates expenditure between private consumption, government consumption and investment. 
In addition to identifying a large number of regions and sectors, the GTAP database also collects data on five factors of production (skilled and unskilled labour, capital, land and resources). In our modelling exercises, we aggregate the database into nine regions - so that New Zealand, its potential FTA partners and its other significant trading partners are identified - and 23 sectors to match the sectoral aggregation used above. The composition of regions and sectors identified in our model in terms of components recognised in the GTAP database are highlighted in Table 4.

We modify the 2001 GTAP database by removing erroneous tariffs on trade between New Zealand and Australia using Rutherford's (2005) "impose" routine and implementing shocks representative of the EU enlargement in 2004, the Australia-US and ASEAN free trade agreements, New Zealand's unilateral tariff reductions and China's accession to the WTO through to 2008. Our simulation exercises focus on possible FTAs likely to have a significant impact on New Zealand. Specifically, using the updated database, we simulate full trade liberalisation between New Zealand and China (NZL-CHN), New Zealand and Japan (NZL-JPN), New Zealand and Korea (NZL-KOR), and New Zealand and ASEAN (NZL-ASN) individually and collectively (NZL-ALL) when (a) only tariffs are removed, and (b) tariffs and NTBs are abolished. ${ }^{11}$ As NTBs typically impose real resource costs, we represent NTBs as iceberg transport costs as described by Samuelson (1954). So, region $i$ 's effective imports from $j\left(M_{i j}^{e}\right)$ equal observed imports $\left(M_{i j}^{o}\right)$ multiplied by a parameter characterising transport technology specific to each bilateral route $\left(\lambda_{i j}\right)$. As $\lambda_{i j}$ is equal to one in or benchmark data, we do not need to recalibrate the database to incorporate NTBs. We simulate reductions in NTBs by setting $\lambda_{i j}$ equal to one plus the relevant

\footnotetext{
${ }^{11}$ Changes in New Zealand welfare following various trade liberalisation scenarios when only tariffs are considered are also reported by Scollay and Gilbert (2001) and Winchester (2005, 2006).
} 
TE.

To assist interpretation of the results, we report trade shares and trade-weighted average tariffs and TEs for New Zealand and four potential FTA partners in Table 5. The data reveal that Japan is the destination for $11.9 \%$ of New Zealand's exports and supplies $7.6 \%$ of this nation's imports. Additionally, Japan imposes a higher tariff on New Zealand goods than other regions considered, and New Zealand's largest average TE import barrier applies to Japan. Other characteristics likely to influence the results include (a) Korean tariffs on New Zealand products are relatively high, and (b) ASEAN accounts for a relatively large share of New Zealand's trade, and (c) ASEAN TEs on New Zealand exports are higher than those imposed by other potential FTA partners.

Annual additions to welfare for each region, which we quantify using the Hicksian equivalent variation in income, measured in 2001 US dollars and as fraction of GDP are presented in Tables 6 and 7 respectively. ${ }^{12}$ The model predicts that the elimination of tariffs on New Zealand-China trade would benefit New Zealand by US\$85.2 million dollars $(0.19 \%$ of GDP) per year. The equivalent New Zealand-Japan FTA simulation produces an estimated welfare gain of US\$394.7 million $(0.86 \%)$. Given the descriptive statistics highlighted above, it is not surprising that the estimated

\footnotetext{
${ }^{12}$ For several reasons, our results should be interpreted as indicative welfare changes resulting from the FTAs considered. First, our estimates of TEs are not linked directly to actual NTBs. Second, as we examine possible FTAs likely to be most important to New Zealand using a parsimonious approach, our regional aggregation does not allow our baseline to account for the Trans-Pacific Strategic Economic Partnership. Similarly, our NZL-ASN simulation does not recognise that New Zealand will likely have FTAs with Malaysia and Thailand before a New Zealand-ASEAN agreement is signed. Third, we only estimate TEs for trade involving New Zealand so, despite the inclusion of Australia in New Zealand-ASEAN trade talks and the high probability that Australia will complete an FTA with Japan before New Zealand, our NZL-ASN and NZL-JPN simulations do not simulate free trade between Australia and, respectively, ASEAN and Japan. Finally, the elimination of all tariff and nontariff barriers is an optimistic representation of the outcome of trade negotiations.
} 
increase in New Zealand welfare is larger in the NZL-JPN simulations than other bilateral agreements. Likewise, the relative magnitudes of New Zealand's welfare gains from the New Zealand-Korea and New Zealand-ASEAN simulations can be rationalised in terms of initial trade flows and tariffs. Simulating tariff reductions in all bilateral relationships results in a welfare gain of US\$679.1 million (1.5\%), which is approximately equal to the sum of welfare changes when the agreements are simulated individually.

Strikingly, welfare declines in Japan, Korea and ASEAN, and China experiences only a small welfare gain (around 12\% of the dollar value of the increase in New Zealand welfare) following the removal of bilateral tariffs on trade with New Zealand. Although some trade diversion is observed, welfare changes for New Zealand's potential partners are largely driven by unrealistic terms of trade movements. Brown (1987) demonstrates that terms of trade movements are considerable in Armingtontype models because national product differentiation implies a country has a monopoly in the market for its exports. Under this assumption, the reallocation of resources and increased export supply resulting from the removal of a nation's tariffs results in the deterioration of the reforming nation's terms of trade. Terms-of-trade movements are severe for New Zealand's FTA partners following trade liberalisation because New Zealand exports large quantities of agricultural commodities. As there is a fixed supply of land, there is limited scope for displaced capital and labour to migrate to agricultural sectors not disrupted by New Zealand produce. The end result is an increase in the supply of manufacturing commodities and an associated price decrease. 
New Zealand welfare changes are much larger when NTBs are removed. In the New Zealand-China FTA simulation the US\$1389.1 (3.1\%) rise in New Zealand welfare is 16.3 times larger than when only tariffs are eliminated. Corresponding ratios for simulations relating to New Zealand's FTAs with Japan, Korea and ASEAN are 10.5, 7.9 and 21.6 respectively. Although these numbers are large, they are not out of line with estimates produced by other authors. For example, Philippidis and Sanjuán (2007b) estimate that the welfare gain to MERCOSUR from the Free Trade Area of the Americas (FTAA) is equivalent to $1.2 \%$ of GDP when tariffs are removed, and $11.6 \%$ when reductions in tariffs and non-tariff barriers are considered. Additionally, the corresponding figures for Morocco due to an EU-Morocco FTA are $0.14 \%$ and 3.3\% (Philippidis and Sanjuán, 2007a).

New Zealand welfare increases by US $\$ 4,155.4$ million $(9.2 \%)$ in the NZL-JPN simulation. This is not a trivial amount - such a welfare gain would increase New Zealand per capita income by US\$2,400 and raise New Zealand's global ranking from 40 to 37 according to figures in the 2007 CIA World Factbook. Furthermore, completing all four FTAs under consideration would boost New Zealand welfare by US\$7,328.8 million (16.3\%), which would raise New Zealand per capita income by US $\$ 4,250$ and improve New Zealand's global ranking to 31 , one place ahead of France. New Zealand's FTA partners also experience welfare gains when tariffs and NTBs are considered. Although these gains are small proportions of each nation's GDP, they are large in absolute value. For example, ASEAN gains US\$1,808.6 million from free trade with New Zealand, which is larger than the absolute increase in New Zealand welfare. 
The inclusion of NTBs in trade negotiations alters the relative standings of the NZLCHN, NZL-KOR and NZL-ASN simulations when ranked according to benefits accruing to New Zealand. Specifically, New Zealand-ASEAN free trade generates the smallest New Zealand welfare increase when only tariffs are eliminated, but the same FTA generates benefits greater than both the NZL-CHN and NZL-KOR FTAs when tariffs and non-tariff barriers are abolished. This is because ASEAN imposes lower tariffs on New Zealand goods (the trade-weighted average tariff on New Zealand products is $5.2 \%)$ than either China $(6.9 \%)$ or Korea $(7.4 \%)$ but ASEAN TEs on New Zealand products $(45.6 \%)$ are higher than those imposed by China $(34.0 \%)$ or Korea $(38.5 \%)$

We decompose sources of New Zealand welfare gains by simulating reductions in tariffs and NTBs for three divisions: agro-food, manufacturing (including resource based sectors) and services. The results are reported in Table $8 .{ }^{13}$ Strikingly, liberalisation of manufacturing improves New Zealand welfare by US\$3,750.1 million - around $50 \%$ of New Zealand's total welfare gain - in the NZL-ALL simulation when tariffs and NTBs are eliminated. In contrast, liberalisation in the manufacturing division accounts for only $9.4 \%$ of the total New Zealand welfare gain when only tariffs are removed. The estimated gains from services liberalisation are small due to low TEs. Examining the FTAs individually reveals that manufacturing liberalisation generates greater gains than agriculture liberalisation in the NZL-CHN and NZL-ASN simulations. Unlike conventional studies of FTAs involving New Zealand - see, for example, Winchester (2005) - these finding suggest that engaging

\footnotetext{
${ }^{13}$ The sum of welfare changes for the different divisions do not equal welfare changes in the "All sectors" row (which, by design, is the same as in first row of results in Table 6) as our decomposition analysis does not consider interaction terms associated with the liberalisations of each division.
} 
in trade negotiations that exclude agriculture can generate substantial gains for New Zealand.

\section{Conclusions}

We estimated welfare changes resulting from four FTAs involving New Zealand when tariffs and NTBs are considered. Reductions in NTBs due to trade negotiations were estimated using a series of gravity equations. We assumed that trade negotiations will reduce NTBs on trade between New Zealand and its potential FTA partners to levels applying to trade between New Zealand and Australia. We justified this approach on the grounds that the two nations have a long-standing FTA and are highly integrated. The results revealed that gains from trade liberalisation are much greater when NTBs are taken into account than in conventional analyses. Our most ambitious simulation indicated that signing comprehensive FTAs with China, Japan, Korea and ASEAN - regions that account for a little over one-quarter of New Zealand's trade - benefits New Zealand by more than $16 \%$ of GDP.

Our analysis has several implications for New Zealand policy makers. First, as the inclusion of NTBs alters the relative benefits to New Zealand from the FTAs considered, it appears that, ceteris paribus, New Zealand's negotiating capital should be used to target an FTA with ASEAN before considering free trade with China and Korea. Conventional examinations, however, suggest a New Zealand-ASEAN FTA should be a relatively low priority. Second, the inclusion of NTBs in FTA simulations suggests that New Zealand's potential FTA partners will experience substantial welfare gains following free trade with New Zealand. This result is in contrast to findings from conventional analyses, which simulation small welfare losses for most 
of New Zealand's potential FTA partners. As a result, New Zealand may find it easier to "sell" FTAs to prospective partners. Finally, given the resistance of many of New Zealand's potential FTA partners to reduce barriers to agricultural trade, the finding that New Zealand can derive significant benefits from FTAs that exclude agriculture is encouraging.

Several caveats to our analysis should be noted before closing. First, due to resource constraints, we infer TEs of NTBs by comparing actual trade data to a free trade benchmark rather than estimating the effects of NTBs using a more accurate "handicraft" approach. Second, our simulations do not capture welfare changes associated with the realisation of economies of scale, dynamic gains due to additions to the capital stock, and productivity improvements due to the transfer of technology. Third, our assumption that trade negotiations will reduce NTBs elsewhere to those within the CER block is ambitious. As Australia-New Zealand economic integration has evolved over several decades, initial reductions in NTBs between New Zealand and other nations may be much less than postulated in our analysis. Finally, as we focused on the effect of NTBs using a parsimonious approach, our study was not able to consider some aspects of New Zealand's bilateral negotiations likely to be important, such as the inclusion of Australia in New Zealand-ASEAN trade negotiations. 


\section{References}

Anderson, J.E. and van Wincoop, E. (2001) Borders, trade and welfare, In Collins, S. and Rodrick D. (eds), Brookings Trade Forum 2001, 207-243.

Anderson, J.E. and van Wincoop (2003) Gravity with gravitas: A solution to the border puzzle, American Economic Review, 93(1), 170-192.

Armington, P. S. (1969) A theory of demand for products distinguished by place of production. IMF Staff Papers, 16, 159-76.

Brown, D. (1987) Tariffs, the terms of trade, and national product differentiation. Journal of Policy Modeling, 9(3), 503-26.

Dimaranan, B.V. ed. (2006) Global Trade, Assistance, and Production: The GTAP 6 Data Base, Center for Global Trade Analysis, Purdue University.

Ferrantino, M. (2006) Quantifying the trade and economic effects of non-tariff measures, OECD Trade Policy Working Paper No. 28.

Krugman. P (1995) “Dutch tulips and emerging markets' (Foreign Affairs, July/August).

Head, K. and Mayer, T., (2002) Illusory border effects, CEPII Working Paper No. 2002-01.

Lejour, A.M., de Mooij, R.A. and Nahuis, R. (2004) EU enlargement: Economic implications for countries and industries, In Belger, H. and Moutos, T. (eds), Managing European Enlargement, Cambridge, MA: MIT Press.

McCallum, J. (1995) National border matter: Canada-US regional trade patterns, American Economic Review, 85(3), 615-23. 
Park, S.C. (2002) Measuring tariffs equivalents in cross border trade in services, Korea Institute for International Economic Policy, Working Paper 02-05.

Philippidis, G. and Carrington, A. (2005) European enlargement and single market accession: A mistreated issue, Journal of Agricultural Economics, 54(3), 479-86.

Philippidis, G. and Sanjuán, A.I. (2007a) An examination of Morocco’s trade options with the EU, Journal of African Economics, 16(2), 259-300.

Philippidis, G. and Sanjuán, A.I. (2007b) An analysis of Mercosur's regional trading agreements, World Economy, 30(3), 504-531.

Samuelson (1954) The transfer problem and transport costs II: Analysis of Effects of Trade Impediments, The Economic Journal, LXIV, 264-89.

Scollay, R., and J. Gilbert, (2001) New regional trading agreements in the Asia Pacific? Washington DC: Institute for International Economics.

Silva, S. and Tenreyro, S. (2006) The log of gravity, Review of Economics and Statistics, 88(4), 659-670.

Rutherford, T.F., (2005) GTAP6inGAMS: The dataset and static model [online], Ann Arbor, MI. Available at http://www.mpsge.org/gtap6/gtap6gams.pdf [Accessed 19 August 2006].

Wei (1996) Intra-National versus international trade: How stubborn are nations in global integration? NBER Working Paper, 5531.

Winchester, N. (2005) Chasing the Rising Sun: A computable general equilibrium evaluation of potential Australasia-Japan FTAs, University of Otago Economics Discussion Paper 0523. 
Winchester N. (2006) Liberating Middle Earth: How will changes in the global trading system affect New Zealand? New Zealand Economic Papers, 40(1), 45-79. 
Table 1: Regression coefficients for aggregated sectors

\begin{tabular}{|c|c|c|c|c|}
\hline & Agro-food & Manufacturing & Services & All sectors \\
\hline \multirow[t]{2}{*}{ Constant } & $0.997^{* * *}$ & $2.182^{*}$ & 0.060 & -0.073 \\
\hline & $(0.381)$ & $(1.244)$ & $(0.243)$ & $(0.389)$ \\
\hline \multirow[t]{2}{*}{$\ln ($ distance $)$} & $-0.620^{* * *}$ & $-0.426^{* * *}$ & $-0.136^{* * *}$ & $-0.365^{* * *}$ \\
\hline & $(0.046)$ & $(0.045)$ & $(0.025)$ & $(0.035)$ \\
\hline \multirow[t]{2}{*}{$\ln$ (production) } & $0.871^{* * *}$ & $0.673^{* * *}$ & $0.841^{* * *}$ & $0.799^{* * *}$ \\
\hline & $(0.029)$ & $(0.099)$ & $(0.046)$ & $(0.040)$ \\
\hline \multirow[t]{2}{*}{$\ln ($ consumption) } & $0.164^{* * *}$ & 0.076 & $0.156^{* * *}$ & $0.200^{* * *}$ \\
\hline & $(0.031)$ & $(0.099)$ & $(0.046)$ & $(0.040)$ \\
\hline \multirow[t]{2}{*}{ Contiguous } & $0.232^{* *}$ & $0.393^{* * *}$ & -0.075 & $0.388^{* * *}$ \\
\hline & $(0.110)$ & $(0.110)$ & $(0.182)$ & $(0.098)$ \\
\hline \multirow[t]{2}{*}{ Colonial } & $0.517^{* * *}$ & $0.580^{* * *}$ & 0.088 & $0.574^{* * *}$ \\
\hline & $(0.168)$ & $(0.193)$ & $(0.124)$ & $(0.185)$ \\
\hline \multirow[t]{2}{*}{ Language } & $0.603^{* * *}$ & $0.464^{* * *}$ & $0.456^{* * *}$ & $0.455^{* * *}$ \\
\hline & $(0.091)$ & $(0.094)$ & $(0.071)$ & $(0.071)$ \\
\hline \multirow[t]{2}{*}{$\ln (1+$ tariff $)$} & -0.563 & $-7.538^{* * *}$ & - & $0.443^{*}$ \\
\hline & $(0.364)$ & $(1.050)$ & & $(0.235)$ \\
\hline \multirow[t]{2}{*}{$\ln (1+$ esub $)$} & $-4.981^{* * *}$ & -1.951 & - & $-4.782^{* * *}$ \\
\hline & $(1.700)$ & (2.189) & & $(1.052)$ \\
\hline \multirow[t]{2}{*}{ NAFTA } & $1.082^{* * *}$ & $0.604^{* *}$ & -0.31 & $0.782^{* * *}$ \\
\hline & $(0.209)$ & $(0.242)$ & $(0.242)$ & $(0.236)$ \\
\hline \multirow[t]{2}{*}{$\mathrm{EU}$} & $0.941^{* * *}$ & $0.231^{*}$ & $0.478^{* * *}$ & $0.442^{* * *}$ \\
\hline & $(0.095)$ & $(0.126)$ & $(0.090)$ & $(0.086)$ \\
\hline \multirow[t]{2}{*}{ MERCOSUR } & $1.377^{* * *}$ & 0.309 & $-2.343^{* * *}$ & 0.398 \\
\hline & $(0.378)$ & $(0.367)$ & $(0.297)$ & $(0.310)$ \\
\hline \multirow[t]{2}{*}{$b_{\mathrm{NZL}, \mathrm{AUS}}$} & $-0.991^{* *}$ & $1.225^{* * *}$ & $-6.597^{* * *}$ & $-1.348^{* * *}$ \\
\hline & $(0.501)$ & $(0.468)$ & $(0.382)$ & $(0.477)$ \\
\hline \multirow[t]{2}{*}{$b_{\mathrm{NZL}, \mathrm{CHN}}$} & $-2.503^{* * *}$ & 0.021 & $-6.302^{* * *}$ & $-1.942^{* * *}$ \\
\hline & $(0.348)$ & $(0.442)$ & $(0.331)$ & $(0.402)$ \\
\hline \multirow[t]{2}{*}{$b_{\mathrm{NZL}, \mathrm{JPN}}$} & $-2.788^{* * *}$ & 0.853 & $-5.947^{* * *}$ & $-1.424^{* * *}$ \\
\hline & $(0.338)$ & $(0.612)$ & $(0.390)$ & $(0.453)$ \\
\hline \multirow[t]{2}{*}{$\mathrm{b}_{\mathrm{NZL}, \mathrm{KOR}}$} & $-2.624^{* * *}$ & 0.329 & $-6.086^{* * *}$ & $-1.746^{* * *}$ \\
\hline & $(0.605)$ & $(0.557)$ & $(0.399)$ & $(0.486)$ \\
\hline \multirow[t]{2}{*}{$\mathrm{b}_{\mathrm{NZL,ASEAN}}$} & $-1.100^{* * *}$ & -0.177 & $-5.846^{* * *}$ & $-1.577^{* * *}$ \\
\hline & $(0.416)$ & $(0.365)$ & $(0.299)$ & $(0.353)$ \\
\hline \multirow[t]{2}{*}{$\mathrm{b}_{\mathrm{AUS}, \mathrm{NZL}}$} & $-0.991^{*}$ & $-1.802^{* * *}$ & $-8.319^{* * *}$ & $-2.849^{* * *}$ \\
\hline & $(0.563)$ & $(0.620)$ & $(0.402)$ & $(0.540)$ \\
\hline
\end{tabular}

Note: $* * *, * *$, and $*$ denote significance at the $1 \%, 5 \%$ and $10 \%$ significance level respectively. Robust standard errors are reported in parentheses. 
Table 1: Regression coefficients for aggregated regression (continued)

\begin{tabular}{lcccc}
\hline & Agro-food & Manufacturing & Services & All sectors \\
\hline $\mathrm{b}_{\text {OTH,NZL }}$ & $-1.834^{* * *}$ & $-3.717^{* * *}$ & $-7.340^{* * *}$ & $-4.441^{* * *}$ \\
& $(0.355)$ & $(0.485)$ & $(0.299)$ & $(0.331)$ \\
$\mathrm{b}_{\text {OTHER }}$ & $-2.470^{* * *}$ & $-1.065^{* * *}$ & $-5.568^{* * *}$ & $-2.627^{* * *}$ \\
& $(0.198)$ & $(0.221)$ & $(0.243)$ & $(0.212)$ \\
Pseudo $\mathrm{R}^{2}$ & 0.9804 & 0.9278 & 0.996 & 0.962 \\
$\mathrm{~N}$ & 22,090 & 13,254 & 11,045 & 46,389
\end{tabular}

Note: $* * *, * *$, and $*$ denote significance at the $1 \%, 5 \%$ and $10 \%$ significance level respectively. Robust standard errors are reported in parentheses.

Table 2: Regression coefficients sign and (5\%) significance summary counts

\begin{tabular}{lcccc}
\hline & Correct sign & Incorrect sign & Insignificant & Total \\
\hline ln(distance) & 21 & 0 & 0 & 21 \\
Contiguous & 8 & 2 & 11 & 21 \\
Colonial & 6 & 1 & 14 & 21 \\
Language & 17 & 0 & 4 & 21 \\
$\ln (1+$ tariff & 10 & 1 & 5 & 16 \\
$\ln (1+$ esub $)$ & 5 & 2 & 6 & 13 \\
NAFTA & 11 & 1 & 9 & 21 \\
EU & 16 & 1 & 4 & 21 \\
MERCOSUR & 8 & 8 & 5 & 21 \\
$\mathrm{~b}_{\text {NZL,AUS }}$ & 11 & 4 & 6 & 21 \\
$\mathrm{~b}_{\text {NZL,CHN }}$ & 17 & 0 & 4 & 21 \\
$\mathrm{~b}_{\text {NZL,JPN }}$ & 15 & 1 & 5 & 21 \\
$\mathrm{~b}_{\text {NZL,KOR }}$ & 16 & 0 & 5 & 21 \\
$\mathrm{~b}_{\text {NZL,ASEAN }}$ & 15 & 0 & 6 & 21 \\
$\mathrm{~b}_{\text {AUS,NZL }}$ & 13 & 0 & 8 & 21 \\
$\mathrm{~b}_{\text {OTH,NZL }}$ & 17 & 0 & 4 & 21 \\
$\mathrm{~b}_{\text {OTHER }}$ & 20 & 0 & 1 & 21 \\
Total & 226 & 21 & 97 & 344 \\
\hline
\end{tabular}


Table 3: CER-normalised ad valorem TEs of NTBs, percent

\begin{tabular}{|c|c|c|c|c|c|c|c|c|}
\hline & \multicolumn{4}{|c|}{ On New Zealand's exports to: } & \multicolumn{4}{|c|}{ On New Zealand's imports from: } \\
\hline & China & Japan & Korea & ASEAN & China & Japan & Korea & ASEAN \\
\hline Vegetables and fruit & 0 & 0 & 54 & 0 & 0 & 0 & 0 & 0 \\
\hline Animal products & 177 & 311 & 185 & 486 & 328 & 315 & 313 & 318 \\
\hline Wool & 0 & 0 & 0 & 0 & 0 & 0 & 0 & 0 \\
\hline Other agriculture & 139 & 67 & 155 & 119 & 0 & 0 & 0 & 0 \\
\hline Forestry & 0 & 0 & 0 & 0 & 110 & 107 & 107 & 112 \\
\hline Fishing & 16,660 & 84 & 305 & 579 & 0 & 0 & 0 & 0 \\
\hline Resources & 14 & 0 & 34 & 23 & 0 & 0 & 0 & 0 \\
\hline Meat products & 0 & 52 & 40 & 9 & 0 & 0 & 0 & 0 \\
\hline Dairy & 71 & 93 & 107 & 76 & 0 & 0 & 0 & 0 \\
\hline Other food products & 88 & 88 & 166 & 0 & 156 & 158 & 158 & 169 \\
\hline TCF & 27 & 27 & 27 & 27 & 54 & 41 & 41 & 42 \\
\hline Wood \& paper & 0 & 0 & 0 & 0 & 73 & 72 & 71 & 78 \\
\hline Chemicals & 36 & 0 & 15 & 31 & 35 & 36 & 35 & 37 \\
\hline Transport equipment & 112 & 13 & 6 & 15 & 56 & 89 & 56 & 57 \\
\hline Other equipment & 24 & 40 & 48 & 24 & 41 & 44 & 39 & 44 \\
\hline Other manuf. & 0 & 0 & 0 & 0 & 28 & 18 & 14 & 17 \\
\hline Trade \& transport & 4 & 0 & 0 & 0 & 0 & 0 & 0 & 0 \\
\hline Comm. & 151 & 0 & 0 & 0 & 0 & 0 & 0 & 0 \\
\hline Financial \& bus. services & 0 & 0 & 0 & 0 & 0 & 0 & 0 & 0 \\
\hline Rec. services & 0 & 0 & 0 & 0 & 0 & 0 & 0 & 0 \\
\hline Public services & 0 & 0 & 0 & 0 & 0 & 0 & 0 & 0 \\
\hline
\end{tabular}


Table 4: Regional and commodity aggregation

\begin{tabular}{|c|c|c|c|}
\hline & \multicolumn{2}{|l|}{ Regions } & Commodities \\
\hline 1. & New Zealand & 1. & Vegetables, fruits and nuts \\
\hline 2. & China & 2. & Animal products \\
\hline 3. & Japan & & Bovine cattle, sheep and goats, horses; animal \\
\hline 4. & Korea & & products not elsewhere classified (nec) \\
\hline \multirow[t]{4}{*}{5.} & $\operatorname{ASEAN}^{1}$ & 3. & Raw milk \\
\hline & Indonesia, Malaysia, Philippines, & 4. & Wool \\
\hline & Singapore, Thailand, Vietnam, Rest of & 5. & Forestry \\
\hline & Southeast Asia & 6. & Fishing \\
\hline \multirow{8}{*}{$\begin{array}{l}6 . \\
7 .\end{array}$} & Australia & 7. & Other agriculture \\
\hline & EU25 & & Paddy rice; wheat; cereal grains; oil seeds; \\
\hline & $\begin{array}{l}\text { Austria, Belgium, Cyprus, Denmark, } \\
\text { Czech Republic, Estonia, Finland, }\end{array}$ & & $\begin{array}{l}\text { sugar cane, sugar beet; plant-based fibres; crops } \\
\text { nec }\end{array}$ \\
\hline & France, Germany, Great Britain, & 9. & Resource based sectors \\
\hline & Greece, Hungary, Ireland, Italy, & & Coal, oil, gas, mineral nec \\
\hline & Latvia, Lithuania, Luxemburg, Malta, & 10. & Meat products \\
\hline & Netherlands, Poland, Portugal, Spain, & & Bovine meat products; meat products nec \\
\hline & Sweden & 11. & Dairy products \\
\hline \multirow{21}{*}{$\begin{array}{l}8 . \\
9 .\end{array}$} & US & 12. & Other food products \\
\hline & $\begin{array}{l}\text { Rest of World (ROW) } \\
\text { All other regions }\end{array}$ & & $\begin{array}{l}\text { Vegetable oils and fats, processed rice, sugar, } \\
\text { food products nec, beverages and tobacco } \\
\text { products }\end{array}$ \\
\hline & & 13. & $\begin{array}{l}\text { Textiles, clothing and footwear } \\
\text { Textiles; wearing apparel, leather products }\end{array}$ \\
\hline & & 14. & $\begin{array}{l}\text { Wood and paper products } \\
\text { Wood products; paper products, publishing }\end{array}$ \\
\hline & & 15. & Chemical and metal products \\
\hline & & & $\begin{array}{l}\text { Petroleum, coal products; chemical, rubber, } \\
\text { plastic products, mineral products nec; ferrous } \\
\text { metals; metal nec; metal products }\end{array}$ \\
\hline & & 16. & Transport equipment \\
\hline & & & $\begin{array}{l}\text { Motor vehicles and parts, transport equipment } \\
\text { nec }\end{array}$ \\
\hline & & 17. & Electronic machinery and equipment \\
\hline & & & $\begin{array}{l}\text { Electronic equipment, machinery and } \\
\text { equipment nec }\end{array}$ \\
\hline & & & Manufactures nec \\
\hline & & 18. & Trade and transport \\
\hline & & & $\begin{array}{l}\text { Trade; transport nec; water transport; air } \\
\text { transport }\end{array}$ \\
\hline & & 19. & Communication \\
\hline & & 20. & Financial and business services \\
\hline & & & $\begin{array}{l}\text { Financial services nec; insurance; business } \\
\text { services nec }\end{array}$ \\
\hline & & 21. & Recreational and other services \\
\hline & & 22. & Public services \\
\hline & & & $\begin{array}{l}\text { Public administration, defence, education, } \\
\text { health }\end{array}$ \\
\hline & & 23. & Other Services \\
\hline & & & $\begin{array}{l}\text { Electricity; gas manufacture, distribution; } \\
\text { water; construction; dwellings }\end{array}$ \\
\hline
\end{tabular}


Table 5: Bilateral trade shares, tariffs and TEs of NTBs, percent

\begin{tabular}{lcccc}
\hline & China & Japan & Korea & ASEAN \\
\hline New Zealand exports & 5.6 & 11.9 & 4.4 & 8.4 \\
Partner exports & 0.2 & 0.3 & 0.2 & 0.3 \\
New Zealand imports & 5.5 & 8.5 & 2.3 & 7.6 \\
Partner imports & 0.4 & 0.6 & 0.5 & 0.4 \\
Tariff on New Zealand exports & 6.9 & 8.6 & 7.4 & 5.2 \\
Tariff on New Zealand imports & 5.1 & 4.6 & 3.5 & 1.6 \\
TE on New Zealand exports & 34.0 & 28.3 & 38.5 & 45.6 \\
TE on New Zealand imports & 45.1 & 61.6 & 41.8 & 44.3 \\
\hline
\end{tabular}


Table 6: Global welfare effects (equivalent variation, 2001 US dollars, million)

\begin{tabular}{|c|c|c|c|c|c|c|c|c|c|c|}
\hline \multirow[b]{2}{*}{ NTBs removed? } & \multicolumn{2}{|c|}{ NZL-CHN } & \multicolumn{2}{|c|}{ NZL-JPN } & \multicolumn{2}{|c|}{ NZL-KOR } & \multicolumn{2}{|c|}{ NZL-ASN } & \multicolumn{2}{|c|}{ NZL-ALL } \\
\hline & $x$ & $\checkmark$ & $x$ & $\checkmark$ & $x$ & $\checkmark$ & $x$ & $\checkmark$ & $x$ & $\checkmark$ \\
\hline New Zealand & 85.2 & 1389.1 & 394.7 & 4155.4 & 149.0 & 1181.6 & 78.0 & 1681.5 & 679.1 & 7328.8 \\
\hline China & 10.6 & 1095.2 & -18.2 & -32.6 & -4.7 & 20.1 & 8.7 & 253.5 & 4.8 & 929.2 \\
\hline Japan & 0.4 & 27.7 & -292.0 & 1069.2 & -15.9 & -16.3 & 4.0 & 146.1 & -282.3 & 918.3 \\
\hline Korea & -2.4 & 3.3 & -11.2 & -38.8 & -130.8 & 501.3 & 1.8 & 73.4 & -124.0 & 234.9 \\
\hline ASEAN & -6.1 & 17.8 & -20.1 & -99.0 & -8.9 & -11.9 & -15.8 & 1808.6 & -43.2 & 1129.1 \\
\hline Australia & -12.5 & -124.3 & -32.6 & -251.4 & -11.0 & -111.3 & -13.7 & -233.0 & -66.0 & -506.5 \\
\hline Europe & -13.9 & -94.0 & -60.8 & -312.4 & -23.0 & -96.0 & -4.6 & -52.7 & -89.2 & -290.8 \\
\hline US & -34.9 & -638.6 & -56.5 & -867.6 & -10.8 & -386.7 & -54.8 & -1326.3 & -158.4 & -2166.1 \\
\hline ROW & -12.6 & 11.6 & -55.7 & -216.3 & -12.9 & -58.2 & 0.7 & 163.6 & -69.7 & -43.3 \\
\hline
\end{tabular}

Source: Simulation results described in text. 
Table 7: Global welfare effects (equivalent variation as a fraction of GDP)

\begin{tabular}{|c|c|c|c|c|c|c|c|c|c|c|}
\hline \multirow[b]{2}{*}{ NTBs removed? } & \multicolumn{2}{|c|}{ NZL-CHN } & \multicolumn{2}{|c|}{ NZL-JPN } & \multicolumn{2}{|c|}{ NZL-KOR } & \multicolumn{2}{|c|}{ NZL-ASN } & \multicolumn{2}{|c|}{ NZL-ALL } \\
\hline & $x$ & $\checkmark$ & $x$ & $\checkmark$ & $x$ & $\checkmark$ & $x$ & $\checkmark$ & $x$ & $\checkmark$ \\
\hline New Zealand & 0.189 & 3.081 & 0.875 & 9.216 & 0.331 & 2.621 & 0.173 & 3.729 & 1.506 & 16.255 \\
\hline China & 0.001 & 0.115 & -0.002 & -0.003 & 0.000 & 0.002 & 0.001 & 0.027 & 0.000 & 0.097 \\
\hline Japan & 0.000 & 0.001 & -0.008 & 0.030 & 0.000 & 0.000 & 0.000 & 0.004 & -0.008 & 0.025 \\
\hline Korea & -0.001 & 0.001 & -0.003 & -0.010 & -0.034 & 0.131 & 0.000 & 0.019 & -0.032 & 0.061 \\
\hline ASEAN & -0.001 & 0.003 & -0.004 & -0.018 & -0.002 & -0.002 & -0.003 & 0.323 & -0.008 & 0.202 \\
\hline Australia & -0.004 & -0.038 & -0.010 & -0.077 & -0.003 & -0.034 & -0.004 & -0.072 & -0.020 & -0.156 \\
\hline Europe & 0.000 & -0.001 & -0.001 & -0.004 & 0.000 & -0.001 & 0.000 & -0.001 & -0.001 & -0.004 \\
\hline US & 0.000 & -0.006 & -0.001 & -0.009 & 0.000 & -0.004 & -0.001 & -0.013 & -0.002 & -0.022 \\
\hline ROW & 0.000 & 0.000 & -0.001 & -0.004 & 0.000 & -0.001 & 0.000 & 0.003 & -0.001 & -0.001 \\
\hline
\end{tabular}

Source: Simulation results described in text. 
Table 8: Decomposition of New Zealand welfare changes (equivalent variation, 2001 US dollars, million)

\begin{tabular}{|c|c|c|c|c|c|c|c|c|c|c|}
\hline \multirow[b]{2}{*}{ NTBs removed? } & \multicolumn{2}{|c|}{ NZL-CHN } & \multicolumn{2}{|c|}{ NZL-JPN } & \multicolumn{2}{|c|}{ NZL-KOR } & \multicolumn{2}{|c|}{ NZL-ASN } & \multicolumn{2}{|c|}{ NZL-ALL } \\
\hline & $x$ & $\checkmark$ & $x$ & $\checkmark$ & $x$ & $\checkmark$ & $x$ & $\checkmark$ & $x$ & $\checkmark$ \\
\hline Agro-food & 66.1 & 283.9 & 385.0 & 2315.0 & 131.2 & 737.4 & 66.7 & 541.4 & 626.8 & 3757.8 \\
\hline Manufacturing & 19.5 & 1099.0 & 11.2 & 1841.2 & 18.5 & 452.5 & 11.5 & 1135.4 & 63.9 & 3750.1 \\
\hline Services & 0.0 & 7.9 & 0.0 & 0.0 & 0.0 & 0.0 & 0.0 & 0.0 & 0.0 & 7.9 \\
\hline All sectors & 85.2 & 1389.1 & 394.7 & 4155.4 & 149.0 & 1181.6 & 78.0 & 1681.5 & 679.1 & 7328.8 \\
\hline
\end{tabular}

Source: Simulation results described in text. 
Table A.1: Countries included in the gravity regressions

\begin{tabular}{llll}
\hline Argentina & Finland & Korea & Singapore \\
Australia & France & Malaysia & South Africa \\
Austria & Germany & Mexico & Spain \\
Bangladesh & Great Britain & Morocco & Sweden \\
Belgium & Greece & Netherlands & Switzerland \\
Brazil & Hong Kong & New Zealand & Taiwan \\
Canada & Hungary & Peru & Thailand \\
Chile & India & Philippines & Turkey \\
China & Indonesia & Poland & USA \\
Columbia & Ireland & Portugal & Venezuela \\
Czech Republic & Italy & Romania & Vietnam \\
Denmark & Japan & Russia & \\
\hline
\end{tabular}


Table A.2: Gravity regression results for agro-food sectors

\begin{tabular}{|c|c|c|c|c|c|c|c|c|c|c|}
\hline & $\begin{array}{c}\text { Vegetables } \\
\text { and fruit }\end{array}$ & $\begin{array}{l}\text { Animal } \\
\text { products }\end{array}$ & Wool & $\begin{array}{c}\begin{array}{c}\text { Other } \\
\text { agriculture }\end{array} \\
\end{array}$ & Forestry & Fishing & Resources & $\begin{array}{c}\text { Meat } \\
\text { products }\end{array}$ & Dairy & $\begin{array}{l}\text { Other food } \\
\text { products }\end{array}$ \\
\hline \multirow[t]{2}{*}{ Constant } & $8.477^{* * *}$ & $10.014^{* * *}$ & $5.635^{* * *}$ & $8.410^{* * *}$ & $10.095^{* * *}$ & $7.891^{* * * *}$ & $13.980^{* * *}$ & $11.120^{* * *}$ & $9.348^{* * *}$ & $9.391^{* * *}$ \\
\hline & $(0.525)$ & $(0.756)$ & $(0.624)$ & $(0.482)$ & $(0.861)$ & $(0.734)$ & $(0.641)$ & $(0.707)$ & $(0.898)$ & $(0.406)$ \\
\hline \multirow[t]{2}{*}{$\ln ($ distance $)$} & $-0.743^{* * *}$ & $-0.730^{* * *}$ & $-0.458^{* * *}$ & $-0.436^{* * *}$ & $-1.059^{* * *}$ & $-0.938^{* * *}$ & $-1.057^{* * *}$ & $-0.761^{* * *}$ & $-0.807^{* * *}$ & $-0.448^{* * *}$ \\
\hline & $(0.068)$ & $(0.096)$ & $(0.087)$ & $(0.059)$ & $(0.125)$ & $(0.105)$ & $(0.117)$ & $(0.079)$ & $(0.126)$ & $(0.044)$ \\
\hline \multirow[t]{2}{*}{ Contiguous } & -0.008 & $0.706^{* * *}$ & -0.563 & 0.172 & $1.274^{* * *}$ & 0.129 & -0.095 & 0.228 & $0.683^{* * *}$ & $0.453^{* * *}$ \\
\hline & $(0.154)$ & $(0.156)$ & $(0.365)$ & $(0.190)$ & $(0.212)$ & $(0.244)$ & $(0.267)$ & $(0.160)$ & $(0.254)$ & $(0.110)$ \\
\hline \multirow[t]{2}{*}{ Colonial } & $0.567^{*}$ & 0.548 & $0.620^{* * *}$ & $0.506^{*}$ & -0.041 & $2.003^{* * *}$ & $-0.553^{*}$ & -0.431 & -0.016 & $0.861^{* * *}$ \\
\hline & $(0.323)$ & $(0.452)$ & $(0.223)$ & $(0.275)$ & $(0.405)$ & $(0.247)$ & $(0.323)$ & $(0.536)$ & $(0.393)$ & $(0.214)$ \\
\hline \multirow[t]{2}{*}{ Language } & $1.138^{* * *}$ & 0.296 & -0.266 & $0.473^{* * *}$ & $0.522^{* * *}$ & 0.312 & $0.636^{* * *}$ & $0.687^{* * *}$ & $0.519^{* * *}$ & $0.575^{* * *}$ \\
\hline & $(0.143)$ & $(0.198)$ & $(0.200)$ & $(0.157)$ & $(0.198)$ & $(0.217)$ & $(0.233)$ & $(0.192)$ & $(0.152)$ & $(0.088)$ \\
\hline \multirow[t]{2}{*}{$\ln (1+$ tariff $)$} & $-2.302^{* * *}$ & $-5.139^{* * *}$ & $-6.256^{* * *}$ & $0.828^{* * *}$ & -6.602 & $-3.479^{* * *}$ & 0.465 & 0.343 & 0.142 & $-1.136^{* *}$ \\
\hline & $(0.637)$ & (1.549) & $(1.571)$ & $(0.232)$ & $(4.267)$ & $(1.346)$ & $(2.516)$ & $(0.423)$ & $(0.380)$ & $(0.578)$ \\
\hline \multirow[t]{2}{*}{$\ln (1+$ esub $)$} & -0.201 & -12.807 & - & 1.503 & - & - & $-14.342^{* * *}$ & -0.344 & $3.710^{* * *}$ & $-12.967^{* * *}$ \\
\hline & $(0.436)$ & $(12.872)$ & & $(1.502)$ & & & (4.401) & (1.581) & $(0.990)$ & $(3.543)$ \\
\hline \multirow[t]{2}{*}{ NAFTA } & $2.305^{* * *}$ & $1.587^{* * *}$ & 0.751 & $1.672^{* * *}$ & 0.340 & $2.181^{* * *}$ & $1.179^{* * *}$ & $1.014^{* * *}$ & -0.124 & $0.615^{* * *}$ \\
\hline & $(0.195)$ & $(0.200)$ & $(0.705)$ & $(0.181)$ & $(0.392)$ & $(0.511)$ & $(0.340)$ & $(0.291)$ & $(0.238)$ & $(0.229)$ \\
\hline \multirow[t]{2}{*}{ EU } & $1.877^{* * *}$ & $0.622^{* * *}$ & $1.848^{* * *}$ & $1.529^{* * *}$ & $1.006^{* * *}$ & $1.508^{* * *}$ & $0.913^{* * *}$ & $1.418^{* * *}$ & $2.552^{* * *}$ & $1.012^{* * *}$ \\
\hline & $(0.171)$ & $(0.194)$ & $(0.309)$ & $(0.146)$ & $(0.293)$ & $(0.186)$ & $(0.335)$ & $(0.172)$ & $(0.244)$ & $(0.135)$ \\
\hline \multirow[t]{2}{*}{ MERCOSUR } & $2.962^{* * *}$ & $-1.414^{* * *}$ & 0.552 & $2.740^{* * *}$ & $-3.514^{* * *}$ & 0.247 & $2.006^{* * *}$ & $0.896^{* *}$ & $1.926^{* * *}$ & $0.438^{*}$ \\
\hline & $(0.285)$ & $(0.347)$ & $(0.411)$ & $(0.535)$ & $(0.537)$ & $(1.524)$ & $(0.383)$ & $(0.363)$ & $(0.316)$ & $(0.240)$ \\
\hline
\end{tabular}


Table A.2: Gravity regression results for agro-food sectors (continued)

\begin{tabular}{|c|c|c|c|c|c|c|c|c|c|c|}
\hline & $\begin{array}{c}\text { Vegetables } \\
\text { and fruit }\end{array}$ & $\begin{array}{c}\text { Animal } \\
\text { products }\end{array}$ & Wool & $\begin{array}{c}\text { Other } \\
\text { agriculture }\end{array}$ & Forestry & Fishing & Resources & $\begin{array}{c}\text { Meat } \\
\text { products }\end{array}$ & Dairy & $\begin{array}{c}\text { Other food } \\
\text { products }\end{array}$ \\
\hline \multirow[t]{2}{*}{$\mathrm{b}_{\mathrm{NZL}, \mathrm{AUS}}$} & $-2.708^{* * *}$ & -0.794 & $-7.231^{* * *}$ & $-0.920^{*}$ & $-6.127^{* * *}$ & $1.591^{* *}$ & $1.224^{*}$ & $-4.520^{* * *}$ & $-1.241^{* *}$ & 0.004 \\
\hline & $(0.492)$ & $(0.602)$ & $(0.672)$ & $(0.553)$ & $(0.731)$ & $(0.721)$ & $(0.674)$ & $(0.750)$ & $(0.515)$ & $(0.357)$ \\
\hline \multirow[t]{2}{*}{$b_{\mathrm{NZL}, \mathrm{CHN}}$} & $-2.182^{* * *}$ & $-1.983^{* * *}$ & $-4.410^{* * *}$ & $-4.283^{* * *}$ & $-1.699^{* * *}$ & $-7.674^{* * *}$ & $-1.582^{* * *}$ & $-4.457^{* * *}$ & $-3.604^{* * *}$ & $-1.817^{* * *}$ \\
\hline & $(0.523)$ & $(0.595)$ & (1.317) & $(0.523)$ & $(0.630)$ & $(0.621)$ & $(0.582)$ & $(0.715)$ & $(0.611)$ & $(0.334)$ \\
\hline \multirow[t]{2}{*}{$b_{N Z L, J P N}$} & $-1.931^{* * *}$ & $-2.775^{* * *}$ & $-6.889^{* * *}$ & $-2.502^{* * *}$ & $-1.909^{* * *}$ & -0.695 & -0.802 & $-6.425^{* * *}$ & $-4.623^{* * *}$ & $-1.816^{* * *}$ \\
\hline & $(0.614)$ & $(0.521)$ & $(0.591)$ & $(0.569)$ & $(0.644)$ & $(0.650)$ & $(0.639)$ & $(0.800)$ & $(0.565)$ & $(0.392)$ \\
\hline \multirow[t]{2}{*}{$b_{\mathrm{NZL}, \mathrm{KOR}}$} & $-3.459^{* * *}$ & $-1.982^{* *}$ & $-7.282^{* * *}$ & $-4.596^{* * *}$ & 0.352 & $-1.740^{* * *}$ & $-3.608^{* * *}$ & $-5.989^{* * *}$ & $-4.946^{* * *}$ & $-2.822^{* * *}$ \\
\hline & $(0.490)$ & $(0.813)$ & $(0.593)$ & $(0.506)$ & $(0.643)$ & $(0.622)$ & $(0.615)$ & $(0.704)$ & $(0.576)$ & $(0.307)$ \\
\hline \multirow[t]{2}{*}{$\mathrm{b}_{\mathrm{NZL}, \mathrm{ASEAN}}$} & $-2.631^{* * *}$ & $-3.534^{* * *}$ & $-7.617^{* * *}$ & $-3.842^{* * *}$ & -0.124 & $-2.672^{* * *}$ & $-2.529^{* * *}$ & $-4.873^{* * *}$ & $-3.802^{* * *}$ & -0.902 \\
\hline & $(0.557)$ & $(0.742)$ & $(0.585)$ & $(0.700)$ & $(0.779)$ & $(0.958)$ & $(0.764)$ & $(0.933)$ & $(0.579)$ & $(0.569)$ \\
\hline \multirow[t]{2}{*}{$\mathrm{b}_{\mathrm{AUS}, \mathrm{NZL}}$} & -0.072 & -0.713 & $-14.128^{* * *}$ & $-2.668^{* * *}$ & -1.019 & $-2.638^{* * *}$ & $-4.962^{* * *}$ & -0.752 & 0.395 & -0.434 \\
\hline & $(0.551)$ & $(0.679)$ & $(0.665)$ & $(0.547)$ & $(0.914)$ & $(0.698)$ & $(0.772)$ & $(0.922)$ & $(0.585)$ & $(0.367)$ \\
\hline \multirow[t]{2}{*}{$\mathrm{b}_{\mathrm{OTH}, \mathrm{NZL}}$} & -0.547 & $-2.873^{* * *}$ & $-8.686^{* * *}$ & $-3.899^{* * *}$ & $-2.907^{* * *}$ & $-1.728^{*}$ & $-3.854^{* * *}$ & -0.736 & -0.088 & $-2.694^{* * *}$ \\
\hline & $(0.671)$ & $(0.762)$ & $(0.702)$ & $(0.613)$ & $(0.945)$ & $(0.889)$ & $(1.063)$ & $(0.914)$ & $(0.755)$ & $(0.356)$ \\
\hline \multirow[t]{2}{*}{$\mathrm{b}_{\text {OTHER }}$} & $-2.123^{* * *}$ & $-2.847^{* * *}$ & $-6.350^{* * *}$ & $-3.407^{* * *}$ & $-2.742^{* * *}$ & -1.558 & $-2.357^{* * *}$ & $-3.908^{* * *}$ & $-4.118^{* * *}$ & $-2.548^{* * *}$ \\
\hline & $(0.525)$ & $(0.756)$ & $(0.624)$ & $(0.482)$ & $(0.861)$ & $(0.734)$ & $(0.641)$ & $(0.707)$ & $(0.898)$ & $(0.406)$ \\
\hline
\end{tabular}

Note: $* * * * *$, and $*$ denote significance at the $1 \%, 5 \%$ and $10 \%$ significance level respectively. Robust standard errors are reported in parentheses. 
Table A.3: Gravity regression results for manufacturing and service sectors

\begin{tabular}{|c|c|c|c|c|c|c|c|c|c|c|c|}
\hline & TCF & $\begin{array}{c}\text { Wood \& } \\
\text { paper }\end{array}$ & Chemicals & $\begin{array}{r}\text { Transport } \\
\text { equipment }\end{array}$ & $\begin{array}{c}\text { Other } \\
\text { equipment }\end{array}$ & $\begin{array}{c}\text { Other } \\
\text { manuf. }\end{array}$ & $\begin{array}{c}\text { Trade \& } \\
\text { transport }\end{array}$ & Comm. & $\begin{array}{c}\text { Financial } \\
\text { \& bus. } \\
\text { services }\end{array}$ & $\begin{array}{c}\text { Rec. } \\
\text { services }\end{array}$ & $\begin{array}{c}\text { Public } \\
\text { services }\end{array}$ \\
\hline \multirow[t]{2}{*}{ Constant } & $10.573^{* * *}$ & $10.495^{* * *}$ & $11.154^{* * *}$ & $11.226^{* * *}$ & $7.528^{* * *}$ & $7.145^{* * *}$ & $10.628^{* * *}$ & $8.223^{* * *}$ & $9.459^{* * *}$ & $8.533^{* * *}$ & $12.303^{* * *}$ \\
\hline & $(0.982)$ & $(0.441)$ & $(0.322)$ & $(0.561)$ & $(0.882)$ & $(0.596)$ & $(0.273)$ & $(0.366)$ & $(0.364)$ & $(0.453)$ & $(0.483)$ \\
\hline \multirow[t]{2}{*}{$\ln ($ distance $)$} & $-0.772^{* * *}$ & $-0.634^{* * *}$ & $-0.558^{* * *}$ & $-0.487^{* * *}$ & $-0.315^{* * *}$ & $-0.438^{* * *}$ & $-0.149^{* * *}$ & $-0.117^{* * *}$ & $-0.100^{* * *}$ & $-0.291^{* * *}$ & $-0.300^{* * *}$ \\
\hline & $(0.119)$ & $(0.047)$ & $(0.037)$ & $(0.064)$ & $(0.055)$ & $(0.067)$ & $(0.035)$ & $(0.033)$ & $(0.033)$ & $(0.041)$ & $(0.048)$ \\
\hline \multirow[t]{2}{*}{ Contiguous } & 0.245 & $0.627^{* * *}$ & $0.303^{* * *}$ & $0.233^{* *}$ & $0.459^{* * *}$ & -0.121 & 0.241 & $-0.164^{*}$ & -0.153 & -0.465 & $-0.969^{* * *}$ \\
\hline & $(0.180)$ & $(0.102)$ & $(0.077)$ & $(0.116)$ & $(0.115)$ & $(0.197)$ & $(0.237)$ & $(0.091)$ & $(0.110)$ & $(0.137)$ & $(0.191)$ \\
\hline \multirow[t]{2}{*}{ Colonial } & 0.294 & $0.268^{* * *}$ & $0.627^{* * *}$ & $-0.666^{*}$ & $0.406^{* * *}$ & $0.641^{* *}$ & -0.025 & -0.042 & 0.302 & $-0.119^{* *}$ & $-0.515^{* *}$ \\
\hline & $(0.394)$ & $(0.291)$ & $(0.171)$ & $(0.343)$ & $(0.154)$ & $(0.308)$ & $(0.132)$ & $(0.240)$ & $(0.194)$ & $(0.285)$ & $(0.255)$ \\
\hline \multirow[t]{2}{*}{ Language } & $0.556^{* * *}$ & $0.373^{* * *}$ & $0.567^{* * *}$ & 0.129 & $0.481^{* * *}$ & $0.599^{* * *}$ & $0.353^{* * *}$ & $0.346^{* * *}$ & $0.423^{* * *}$ & 0.274 & $0.634^{* * *}$ \\
\hline & $(0.162)$ & $(0.087)$ & $(0.078)$ & $(0.152)$ & $(0.095)$ & $(0.200)$ & $(0.092)$ & $(0.098)$ & $(0.092)$ & $(0.117)$ & $(0.191)$ \\
\hline \multirow[t]{2}{*}{$\ln (1+$ tariff $)$} & $-3.667^{* *}$ & $-5.541^{* * *}$ & $-7.898^{* * *}$ & $-7.934^{* * *}$ & $-12.354^{* * *}$ & -1.096 & - & - & - & - & - \\
\hline & (1.597) & $(0.963)$ & $(0.841)$ & (1.147) & $(1.735)$ & $(3.060)$ & & & & & \\
\hline \multirow[t]{2}{*}{$\ln (1+$ esub $)$} & 0.784 & $8.035^{* * *}$ & $8.451^{* * *}$ & $48.347^{* * *}$ & 10.634 & $65.822^{* * *}$ & - & - & - & - & - \\
\hline & (1.159) & $(2.775)$ & $(2.296)$ & $(9.222)$ & $(22.137)$ & (11.493) & & & & & \\
\hline \multirow[t]{2}{*}{ NAFTA } & -0.296 & $0.680^{* * *}$ & 0.255 & $1.397^{* * *}$ & $0.699^{* *}$ & $0.939^{* * *}$ & $-0.724^{* *}$ & 0.138 & -0.173 & 0.027 & $0.429^{*}$ \\
\hline & $(0.290)$ & $(0.170)$ & $(0.160)$ & $(0.223)$ & $(0.215)$ & $(0.365)$ & $(0.317)$ & $(0.182)$ & $(0.243)$ & $(0.230)$ & $(0.235)$ \\
\hline \multirow[t]{2}{*}{ EU } & 0.005 & $0.292^{* * *}$ & $0.260^{* * *}$ & $0.690^{* * *}$ & 0.117 & -0.263 & $0.393^{* * *}$ & $0.814^{* * *}$ & 0.711 & -0.058 & $-0.582^{* * *}$ \\
\hline & $(0.166)$ & $(0.096)$ & $(0.082)$ & $(0.182)$ & $(0.145)$ & $(0.221)$ & $(0.123)$ & $(0.099)$ & $(0.097)$ & $(0.148)$ & $(0.168)$ \\
\hline \multirow[t]{2}{*}{ MERCOSUR } & -0.083 & 0.008 & $0.507^{* * *}$ & $1.978^{* * *}$ & $0.953^{* * *}$ & $-1.106^{* *}$ & $-2.371^{* * *}$ & $-2.024^{* * *}$ & -2.535 & $-1.264^{* * *}$ & $-1.903^{* * *}$ \\
\hline & $(0.227)$ & $(0.181)$ & $(0.100)$ & $(0.429)$ & $(0.306)$ & $(0.541)$ & $(0.363)$ & $(0.110)$ & $(0.159)$ & $(0.180)$ & $(0.196)$ \\
\hline
\end{tabular}


Table A.3: Gravity regression results for manufacturing and service sectors (continued)

\begin{tabular}{|c|c|c|c|c|c|c|c|c|c|c|c|}
\hline & TCF & $\begin{array}{c}\text { Wood \& } \\
\text { paper }\end{array}$ & Chemicals & $\begin{array}{l}\text { Transport } \\
\text { equipment }\end{array}$ & $\begin{array}{c}\text { Other } \\
\text { equipment }\end{array}$ & $\begin{array}{l}\text { Other } \\
\text { manuf. }\end{array}$ & $\begin{array}{c}\text { Trade \& } \\
\text { transport }\end{array}$ & Comm. & $\begin{array}{c}\text { Financial } \\
\& \text { bus. } \\
\text { services }\end{array}$ & $\begin{array}{c}\text { Rec. } \\
\text { services }\end{array}$ & $\begin{array}{c}\text { Public } \\
\text { services }\end{array}$ \\
\hline \multirow[t]{2}{*}{$\mathrm{b}_{\mathrm{NZL}, \mathrm{AUS}}$} & $2.015^{* * *}$ & 0.414 & $0.866^{* * *}$ & $-1.744^{* * *}$ & $2.057^{* * *}$ & -0.261 & $-6.227^{* * *}$ & $-6.839^{* * *}$ & $-6.587^{* * *}$ & $-6.674^{* * *}$ & $-8.789^{* * *}$ \\
\hline & $(0.655)$ & $(0.476)$ & $(0.277)$ & $(0.414)$ & $(0.359)$ & $(0.522)$ & $(0.286)$ & $(0.269)$ & $(0.277)$ & $(0.337)$ & $(0.363)$ \\
\hline \multirow[t]{2}{*}{$\mathrm{b}_{\mathrm{NZL}, \mathrm{CHN}}$} & $1.336^{*}$ & 0.547 & $-1.021^{* * *}$ & $-4.975^{* * *}$ & -0.185 & 1.005 & $-6.251^{* * *}$ & $-7.179^{* * *}$ & $-5.763^{* * *}$ & $-6.502^{* * *}$ & $-7.755^{* * *}$ \\
\hline & $(0.713)$ & $(0.625)$ & $(0.280)$ & $(0.440)$ & $(0.315)$ & $(0.679)$ & $(0.205)$ & $(0.285)$ & $(0.260)$ & $(0.332)$ & $(0.375)$ \\
\hline \multirow[t]{2}{*}{$\mathrm{b}_{\mathrm{NZL}, J P N}$} & -0.150 & -0.098 & $0.974^{* * *}$ & $-2.237^{* * *}$ & $-1.096^{* * *}$ & -0.322 & $-5.651^{* * *}$ & $-6.765^{* * *}$ & $-5.581^{* * *}$ & $-6.351^{* * *}$ & $-7.929^{* * *}$ \\
\hline & $(0.726)$ & $(0.494)$ & $(0.297)$ & $(0.490)$ & $(0.291)$ & $(0.525)$ & $(0.331)$ & $(0.283)$ & $(0.251)$ & $(0.335)$ & $(0.381)$ \\
\hline \multirow[t]{2}{*}{$b_{\mathrm{NZL}, \mathrm{KOR}}$} & $1.346^{*}$ & -0.360 & 0.366 & $-1.983^{* * *}$ & $-1.538^{* * *}$ & -0.942 & $-5.623^{* * *}$ & $-6.775^{* * *}$ & $-5.786^{* * *}$ & $-6.642^{* * *}$ & $-7.961^{* * *}$ \\
\hline & $(0.698)$ & $(0.530)$ & $(0.319)$ & $(0.531)$ & $(0.303)$ & $(0.611)$ & $(0.332)$ & $(0.276)$ & $(0.259)$ & $(0.350)$ & $(0.386)$ \\
\hline \multirow[t]{2}{*}{$b_{\text {NZL,ASEAN }}$} & $1.320^{*}$ & 0.839 & $-0.778^{* *}$ & $-2.309^{* * *}$ & -0.160 & $-1.077^{*}$ & $-5.651^{* * *}$ & $-6.524^{* * *}$ & $-5.199^{* * *}$ & $-6.180^{* * *}$ & $-7.841^{* * *}$ \\
\hline & $(0.782)$ & $(0.625)$ & $(0.387)$ & $(0.684)$ & $(0.353)$ & $(0.579)$ & $(0.370)$ & $(0.357)$ & $(0.342)$ & $(0.372)$ & $(0.390)$ \\
\hline \multirow[t]{2}{*}{$\mathrm{b}_{\mathrm{AUS}, \mathrm{NZL}}$} & -0.617 & -0.601 & $-1.290^{* * *}$ & $-2.243^{* * *}$ & $-1.670^{* * *}$ & $-2.598^{* * *}$ & $-7.332^{* * *}$ & $-7.678^{* * *}$ & $-9.689^{* * *}$ & $-6.985^{* * *}$ & $-10.212^{* * *}$ \\
\hline & $(0.704)$ & $(0.531)$ & $(0.308)$ & $(0.513)$ & $(0.412)$ & $(0.632)$ & $(0.346)$ & $(0.295)$ & $(0.296)$ & $(0.373)$ & $(0.449)$ \\
\hline \multirow[t]{2}{*}{$\mathrm{b}_{\mathrm{OTH}, \mathrm{NZL}}$} & $-2.220^{* * *}$ & $-2.836^{* * *}$ & $-2.784^{* * *}$ & $-4.082^{* * *}$ & $-3.770^{* * *}$ & $-3.530^{* * *}$ & $-6.650^{* * *}$ & $-7.000^{* * *}$ & $-8.023^{* * *}$ & $-6.294^{* * *}$ & $-8.969^{* * *}$ \\
\hline & $(0.763)$ & $(0.539)$ & $(0.304)$ & $(0.581)$ & $(0.409)$ & $(0.534)$ & $(0.391)$ & $(0.304)$ & $(0.292)$ & $(0.365)$ & $(0.450)$ \\
\hline \multirow[t]{2}{*}{$\mathrm{b}_{\text {OTHER }}$} & -0.387 & $-1.831^{* * *}$ & $-1.108^{* * *}$ & $-2.370^{* * *}$ & $-0.571^{* *}$ & $-1.775^{* * *}$ & $-5.342^{* * *}$ & $-6.022^{* * *}$ & $-5.183^{* * *}$ & $-5.801^{* * *}$ & $-7.349^{* * *}$ \\
\hline & $(0.434)$ & $(0.314)$ & $(0.188)$ & $(0.379)$ & $(0.223)$ & $(0.356)$ & $(0.307)$ & $(0.256)$ & $(0.222)$ & $(0.308)$ & $(0.285)$ \\
\hline
\end{tabular}

